\title{
Histological Study of the Effect of Proton Pump Inhibitor (Esomeprazole) on the Renal Cortex of Adult Male Albino Rats
}

\section{Original Article}

\author{
Youstina S. Salib, Samah Kandeel, Kawther A. El-Mehey, and \\ Abd-Elmon'em F. Zamzam
}

Histology and Cell Biology Department, Faculty of Medicine, Tanta University

\begin{abstract}
Background: Esomeprazole is one of the proton pump inhibitors used in the treatment of gastrointestinal disorders. In spite of its safety, it can induce many side effects, especially acute interstitial nephritis that may progress into acute renal failure. Aim: This work aimed to investigate the effect of proton pump inhibitor (esomeprazole) on the histological structure of the renal cortex of adult male albino rats, as well as the effect of stoppage of that exposure.

Materials and methods: 30 adult male albino rats were divided into three groups (10 rats each); control, esomeprazole group: rats received $5 \mathrm{mg} / \mathrm{kg}$ /day esomeprazole orally for 4weeks, and recovery group by which rats received esomeprazole $5 \mathrm{mg} / \mathrm{kg}$ /day orally, then left for another 4 weeks without treatment. After that, the renal cortex obtained and processed for light and transmission electron microscopic examination.

Results: Esomeprazole group showed shrunken glomeruli with widening of Bowman's space, vacuolated glomerular and tubular cells, with darkly stained nuclei, focal interruption of PAS reaction in the brush border of PCTs besides statistically significant decrease in the mean optical density for PAS when compared with control, and focal ultrastructural changes in renal corpuscles, proximal and distal convoluted tubules. In recovery group; partial improvement of the previous histopathological findings observed.

Conclusion: Esomeprazole induced histopathological changes in the structure of the renal cortex of adult male albino rats, which could be partially improved if left to recover.
\end{abstract}

Received: 12 February 2019, Accepted: 22 March 2019

Key Words: Esomeprazole, light and electron microscope, PAS, rats renal cortex.

Corresponding Author: Youstina S. Salib, MSc, Histology Department, Faculty of Medicine, Tanta University, Egypt, Tel.: +2040 3352488, E-mail: dr_youstina_samoil@hotmail.com

ISSN: $1110-0559$, Vol. 42, No. 3

\section{INTRODUCTION}

Proton pump inhibitors (PPIs) are drugs widely prescribed for many patients to treat gastrointestinal disorders, such gastro-esophageal reflux, peptic ulcer (particularly related to Helicobacter pylori infection), acid-related dyspepsia and gastro-duodenal lesions. They reduce gastric acid production by inhibiting the $(\mathrm{H}+/ \mathrm{K}+$ ATPase) located on the secretory surface of gastric parietal cells $s^{[1,2]}$

There are five PPIs available in the market, including omeprazole, lansoprazole, pantoprazole, rabeprazole and esomeprazole. It has been shown that continuous maintenance treatment with esomeprazole provides more effective acid suppression than other PPIs in patients with gastric esophageal reflux ${ }^{[3]}$. Esomeprazole has slower plasma clearance, which results in higher plasma concentrations. This offers better clinical efficacy and more effective management of the hyperacidity diseases ${ }^{[4]}$.

While PPIs are remarkably safe and no serious side effects were noticed ${ }^{[5]}$; case reports of acute interstitial nephritis (AIN) noticed in the last decades. In 1992, the first single case was published by Ruffenach and his colleagues $^{[6]}$, followed by many reported cases of AIN after pantoprazole and omeprazole exposure ${ }^{[7-9]}$. Most of the published studies described and discussed the PPIs induced AIN clinically and statistically ${ }^{[10-12]}$.

Although only a small proportion of patients develop AIN from PPIs, these drugs considered now one of the important common drugs induced AIN in the developed countries due to their prolonged use. It was noticed recently that prolonged PPIs exposure is associated with increased risk of incident chronic kidney diseases and even death ${ }^{[13-16]}$. Moreover, certain cases with PPIs induced AIN presented sub-clinically leading to gradual, progressive kidney failure ${ }^{[17]}$.

So, the aim of the present study is to investigate the effect of esomeprazole on the histological structure of the renal cortex of adult male albino rats, as well as the effect of stoppage of that exposure. This is through using light and electron microscopic study. 


\section{MATERIALS AND METHODS}

\subsection{Drugs}

Esomeprazole is manufactured by AstraZeneca,(Egypt) in the form of sachet containing $10 \mathrm{mg}$. Each sachet was dissolved in $10 \mathrm{ml}$ distilled water then $5 \mathrm{mg} / \mathrm{kg}(1 \mathrm{ml}$ of the prepared solution), was given orally by an intragastric tube once daily for 4 weeks ${ }^{[18,19]}$

\subsection{The experimental animals}

This work was carried out on 30 adult male albino rats, their weights ranged between 100 and 150 grams. All animals were housed in suitable clean properly ventilated cages under similar conditions and were fed on a similar commercial laboratory diet and water. They were acclimatized to their environment at least one week before starting the experiment.

They divided into three groups (10 rats each); control group: kept without treatment (used to study the normal histological structure of the renal cortical tissue); they were sacrificed at the same period of their corresponding experimental group, Esomeprazole group: by which rats given $5 \mathrm{mg} / \mathrm{kg} /$ day esomeprazole orally for 4 week, and Recovery group: by which rats given $5 \mathrm{mg} / \mathrm{kg} / \mathrm{day}$ esomeprazole orally for 4 weeks, then left for another 4 weeks without treatment.

At the appropriate time; animals were sacrificed after intra peritoneal injection of sodium thiopental $(40 \mathrm{mg} / \mathrm{kg})^{[20]}$. Then specimens of the renal cortex obtained and processed for light and electron microscopic examination.

\subsection{Preparation of specimens for light microscopic study}

The renal cortical specimens were taken and immediately fixed in $10 \%$ formol saline solution for 24 hours. Then dehydrated in ascending grades of ethyl alcohol followed by clearance in two changes of xylol 30 minutes each. After that, impregnation was done in pure soft paraffin for 2 hours at $60^{\circ} \mathrm{C}$ followed by embedding in hard paraffin. Finally, sections of 5 um obtained.

\subsubsection{Haematoxylin \&Eosin (H. \&E.) stain}

Sections were de-waxed and hydrated through graded alcohol, and stained with Harris' hematoxylin for 2-5 min, then differentiation in $1 \%$ acid alcohol $(1 \%$ HCL in $70 \%$ alcohol) for 5-10 seconds was done. At that time, sections washed well in running tap water for $5 \mathrm{~min}$, and stained with $1 \%$ eosin for 1-3 min. Lastly, dehydration through ascending grades of alcohol, clearance by xylol and mounting with Canada balsam. Nucleus appeared blue while the cytoplasm appeared pink.

\subsubsection{Periodic Acid Schiff's (PAS) stain}

PAS stain used to demonstrate polysaccharides. By which, sections were deparaffinized, hydrated and immersed in $1 \%$ periodic acid for 8 minutes then washed under running tap water, and placed in Schiff's reagent for 15 minutes (the sections become light pink color during this step). After that, sections were washed under running tap water for 5 minutes (immediately the sections turn dark pink color). Finally, sections dehydrated through ascending grades of alcohol, cleared in xylol and mounted in Canada balsam. Deep red or magenta staining of mucopolysaccharides appeared while nuclei stained blue.

\section{Statistical analysis for optical density of PAS stain}

The software (Image J) (National Institute of Health, Bethesda, Maryland, USA) was used to measure the optical density of PAS stain in all groups of the present research. By which, $10 \mathrm{LM}$ images stained with PAS at a magnification X 400 from each group were used.

The data were analyzed by student t-test after evaluation of f-test. Then the collected data were expressed as (mean $\pm \mathrm{SD}$ ). Results finally considered to be significant when $P<0.05$.

\subsection{Preparation of specimens for electron microscopic study}

Specimens were fixed in $2.5 \%$ phosphate buffered glutaraldehyde, processed and embedded in epoxy resin. Semithin sections ( $1 \mu \mathrm{m}$ thick) were stained with toluidine blue and examined to choose the part to be studied by transmission electron microscope. Ultrathin sections of ( $75 \mathrm{~nm}$ thick) were picked up on 200 mesh uncoated copper grids, stained with uranyl acetate and counter-stained with lead citrate. Finally, examined by (JEOL-JEM-100 SX electron microscope, Japan) at The Electron Microscopic Unit, Faculty of Medicine, Tanta University, Egypt ${ }^{[21]}$.

\section{RESULTS}

\subsection{Light microscopic results}

\subsubsection{Haematoxylin and eosin results}

Haematoxylin \& eosin stained sections of the control group showed renal corpuscles (malpighian corpuscles) formed of a tuft of capillaries (glomerulus) enveloped by regular continuous Bowman's capsule, in which Bowman's capsule parietal layer was lined by simple squamous epithelial cells. Moreover, at the vascular pole of each observed Malpighian corpuscle, a darkly stained nucleated area corresponding to juxtaglomerular apparatus was observed, consisting of densely packed epithelial cells of macula densa and nearby juxtaglomerular cells. Considering PCTs; they showed narrow lumen and lined by 4 to 6 large cubical or low columnar cells, with deeply acidophilic cytoplasm. Their nuclei were rounded and nearly basal or central in position with ill distinct cell boundaries and striated luminal border. While, DCTs had wide lumen and were lined with 5-8 low cubical cells with less acidophilic cytoplasm and euchromatic nuclei, in addition to distinct cell boundaries without brush border (Figure 1a-c). On the other hand, esomeprazole group revealed some shrunken glomeruli with widening of Bowman's space 
while others showed congestion, and some glomerular cells showed vacuolated cytoplasm and darkly stained nuclei. Regarding tubular cells, some showed vacuolated cytoplasm and darkly stained nuclei together with nuclear extrusion into tubular lumen as well as intraluminal debris. Furthermore, congested intertubular capillaries were encountered (Figure 2a, b). While, the recovery group showed regression of some of the microscopic lesions and persistence of others. Through which, few of the renal corpuscles were shrunken with widening of the capsular space, and few cortical tubular cells revealed vacuolation and deeply stained nuclei (Figure2c, d).

\subsubsection{PAS results}

Examination of PAS stained sections of the control group revealed strong PAS +ve reaction in the basement membrane of the parietal layer of Bowman's capsule and in the basement membrane of convoluted tubules as well as brush borders of PCTs. For esomeprazole group; minimal PAS reaction in the brush border of some PCTs with its focal interruption seen. While, PAS stained sections of the recovery group showed focal loss of PAS reaction in the brush border of few PCTs (Figure 3a-c).

\section{Statistical results for the optical density of PAS stain}

As assessed by the image analyzer, Esomeprazole group showed statistically significant decrease in the mean optical density for PAS when compared with control group, Moreover, Recovery group revealed non-significant change in the mean optical density for PAS when compared with control group while significant increase when compared with esomeprazole group (Histogram 1).

\subsection{Electron microscopic results}

Electron microscopic (EM) results of the glomerular basement membrane and podocytes of the control renal cortex showed homogenous and trilamellar glomerular basement membrane, formed of outer and inner electron lucent layers and a middle electron dense layer. The podocytes' cytoplasm contained euchromatic nucleus and had a cell body from which cytoplasmic extensions arise forming primary (major) processes. From these primary processes, secondary (minor) processes or pedicles arise and terminated by feet-like expansions on the basal lamina of the capillary wall. Esomeprazole group revealed focal ultrastructural changes in some renal corpuscles, proximal and distal convoluted tubules. There was focal thickening of the glomerular basement membrane. While, some podocytes showed effacement of the secondary foot processes and fusion of their secondary processes. Moreover, irregular shaped nucleus. Considering the recovery group; it showed persistence of some of the EM changes of the structures of the renal cortex. These were in the form of areas of fusion and effacement of few podocytes' secondary foot processes (Figure 4a-c).

As regards EM examination of the control PCTs revealed cells that resting on a thin basement membrane with numerous thin, long apical microvilli forming its characteristic brush border besides pinocytotic vesicles and lysosomes. Each cell of the proximal tubule contained a single large, spherical euchromatic nucleus, nearly central in position, and their chromatin was clumped along the inner nuclear membrane. Moreover, basal plasma membrane enfolding's noticed besides, numerous, elongated mitochondria arranged in the basal half of the cell parallel to the long axis of the cells (palisade arrangement). For esomeprazole group; it showed some cells with cytoplasmic vacuoles, dense bodies and loss of mitochondrial palisade arrangement. In the recovery group; few PCT cells revealed disrupted apical cell membrane with extrusion of its organelles into their lumen (Figure 5a-c).

Considering EM examination of the control DCTs showed cubical cells with few short scattered microvilli on their luminal surfaces. Each cell of DCTs contained a rounded or ovoid nucleus with less extended chromatin and large nucleolus besides large numbers of mitochondria in its basal part. Some DCTs cells in esomeprazole group showed widening of the intercellular spaces and irregular nuclear outlines, together with loss of basal arrangement of its mitochondria. Few DCTs of recovery group showed mild disarrangement of the mitochondria (Figure 6a-c). 


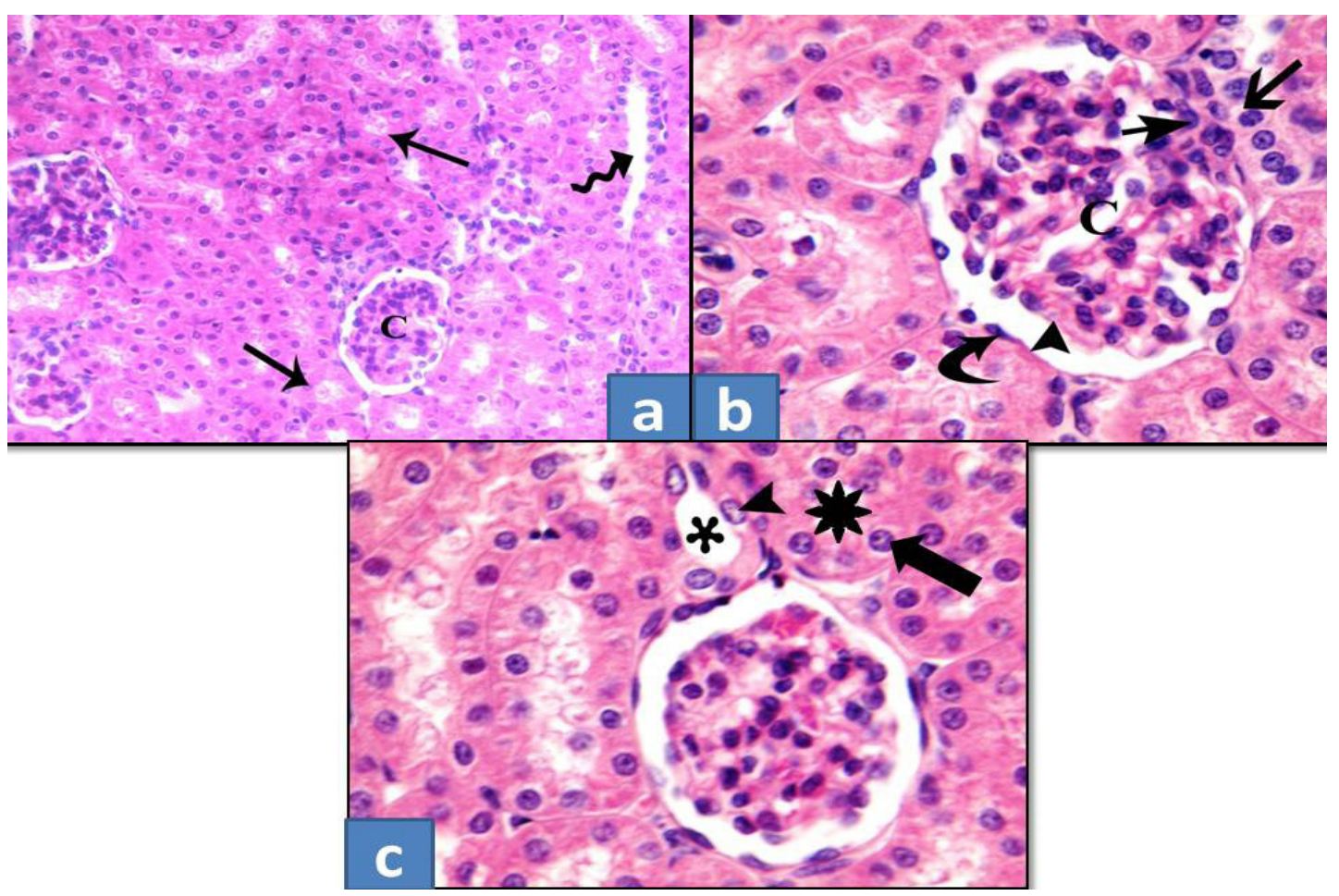

Fig. 1: Photomicrographs of the renal cortex of the control group stained by H.\&E. showing: a) renal corpuscles (C), proximal convoluted tubules (PCTs) $(\rightarrow)$, and distal convoluted tubules (DCTs) ( $\neg)(\mathrm{x} 400)$. b) renal corpuscle with tuft of capillaries (C), lined by visceral layer of Bowman's capsule ( $)$ and simple squamous cells lining the parietal layer $(\hookrightarrow)$,juxtaglomerular apparatus at the vascular pole consisting of densely packed epithelial cells of macula densa $(\rightarrow)$ and nearby juxtaglomerular cells (short arrow) (x 1000). c) PCTs with narrow lumen ( cytoplasm, brush border and basal basophilic nuclei $(\rightarrow)$,DCTs with wide lumen $(*)$, lined by low cubical cells with less acidophilic cytoplasm, distinct cell boundaries and euchromatic nuclei ( $(\mathrm{x}$ 1000).

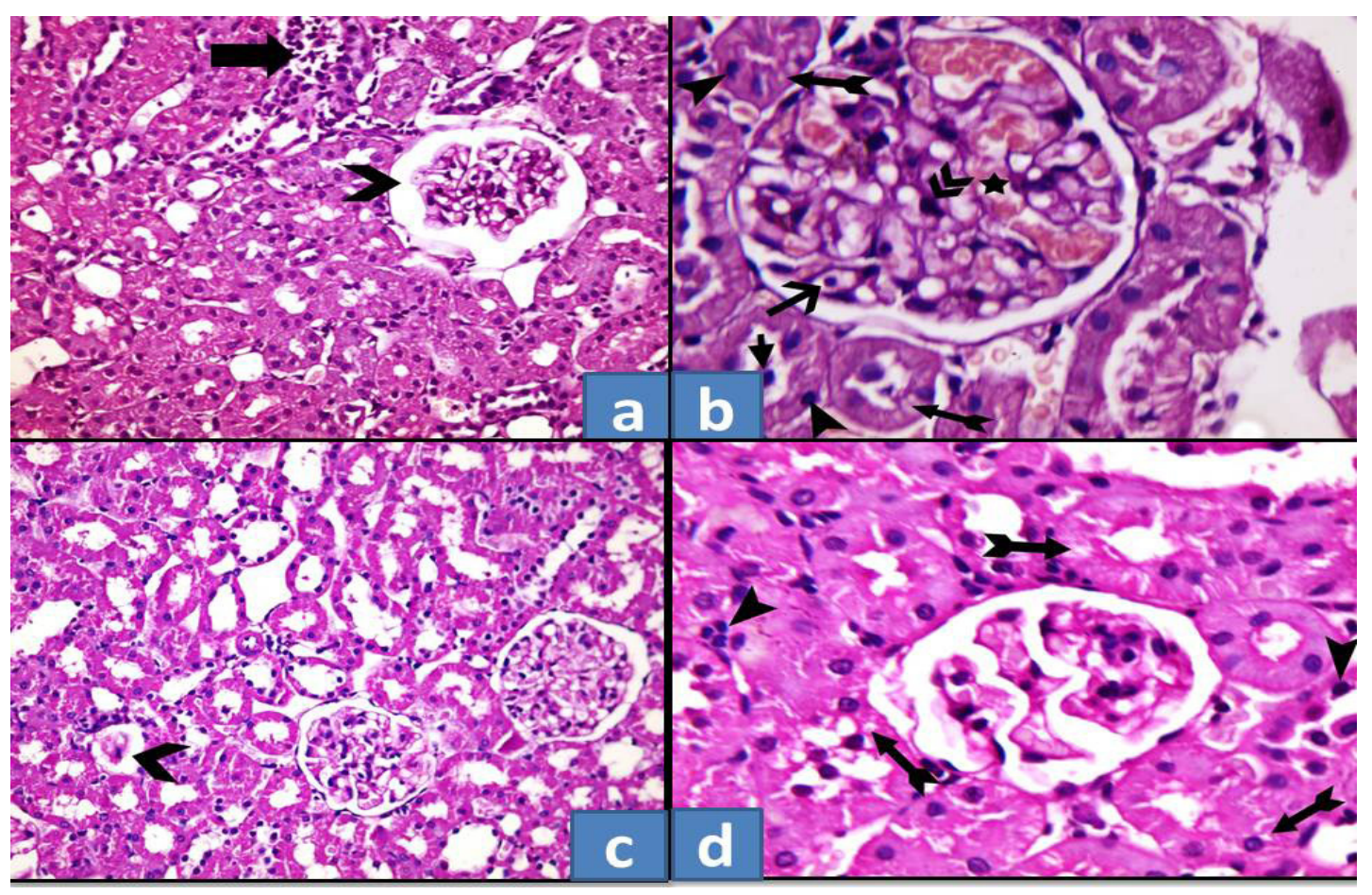

Fig. 2: Photomicrographs of the renal cortex stained by H. \& E. showing a) Esomeprazole group with shrunken glomerulus with widening of Bowman's space (arrow head) and mononuclear cellular infiltration ( $\vec{\longrightarrow}$ ) (H\&E X400). b) Esomeprazole group with congested glomerulus ( and darkly stained glomerular cell nuclei $(\square)$, vacuolated tubular cells $(\rightarrow$ ) with darkly stained nuclei $(\rightarrow)$ and nuclear extrusion into tubular lumen (short arrow) (H\&E X1000). c) Recovery group with few shrunken glomeruli, widening of Bowman's space (arrow head) (H\&E X400). d) Recovery group with few cortical tubular cells with vacuolation $(\diamond)$ and darkly stained nuclei $(\triangleright)$ (H\&E X1000). 


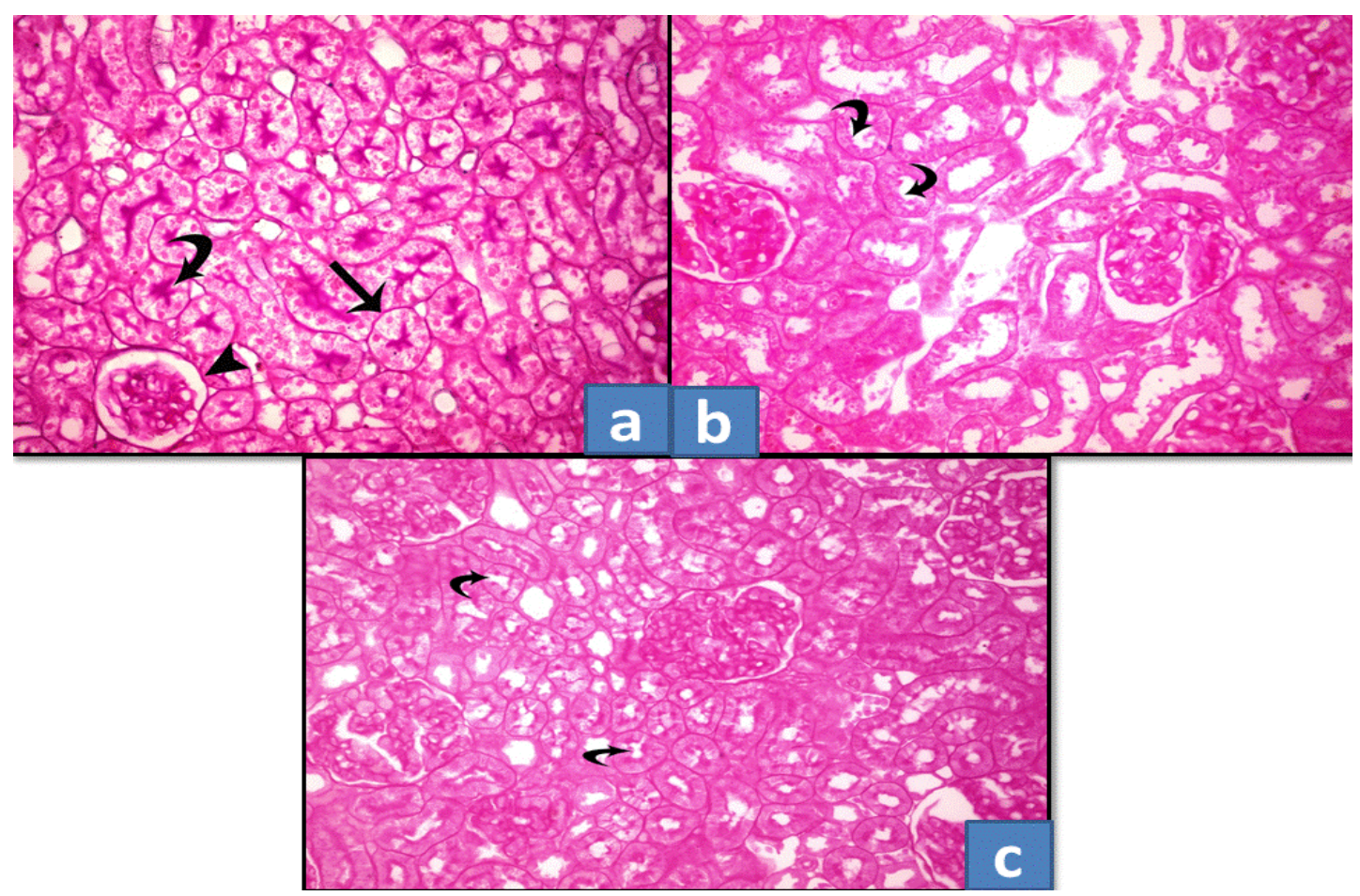

Fig. 3: Photomicrographs of PAS stained sections showing: a) control group with PAS +ve reaction of the basement membrane of the parietal layer of Bowman's capsule $(\rightarrow)$, cortical tubule basement membrane $(\rightarrow)$, and the brush border of PCTs $(\hookrightarrow)$. b) Esomeprazole group with apparent minimal PAS reaction and focal interruption of the brush border of some PCTs $(\hookrightarrow)$. c) Recovery group with focal loss of PAS reaction in the brush border of few PCTs $(\hookrightarrow)$ (PAS X 400).

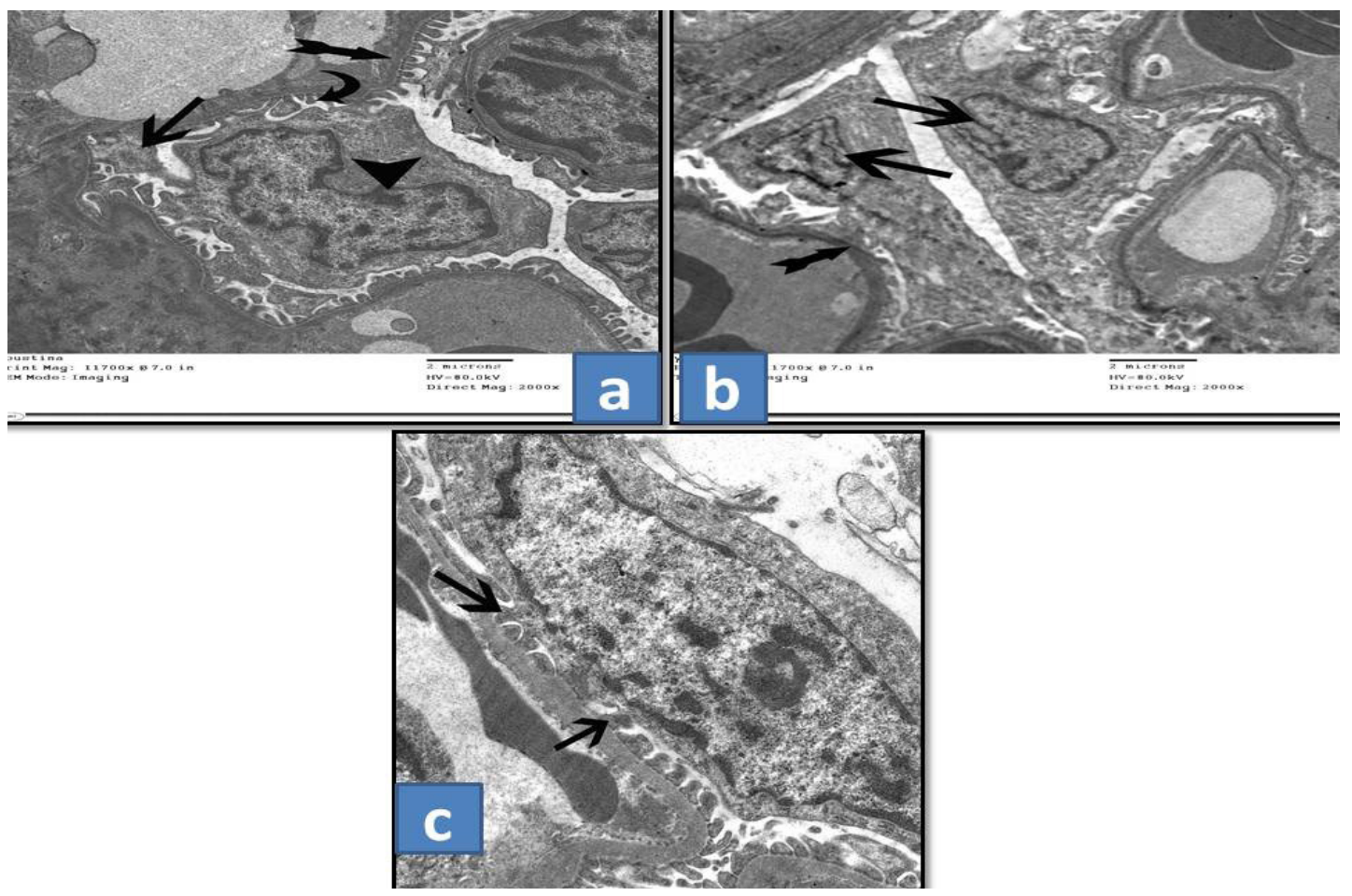

Fig. 4: EM of glomerular basement membrane and podocytes showing: a) Control group with glomerular trilamellar basement membrane formed of outer and inner electron lucent and a middle electron dense layer $(\prec)$, podocytes' cytoplasm contained euchromatic nucleus $(\triangleright)$, cell body from which raised cytoplasmic extensions that form primary (major) processes $(\rightarrow$ ), and secondary (minor) processes terminated by feet-like expansions on the basal lamina of the capillary wall ( $\hookrightarrow$ )(Mic. Mag. X 2000). b) Esomeprazole group with focal thickening of basement membrane ( $\rightarrow$ ), and effacement and fusion of secondary feet processes of some podocytes, and irregular shaped nucleus $(\rightarrow$ ) (Mic. Mag.x2000). c) Recovery group showing areas of fusion and effacement of few podocytes' secondary foot processes $(\rightarrow)$ (Mic. Mag. X 4000). 


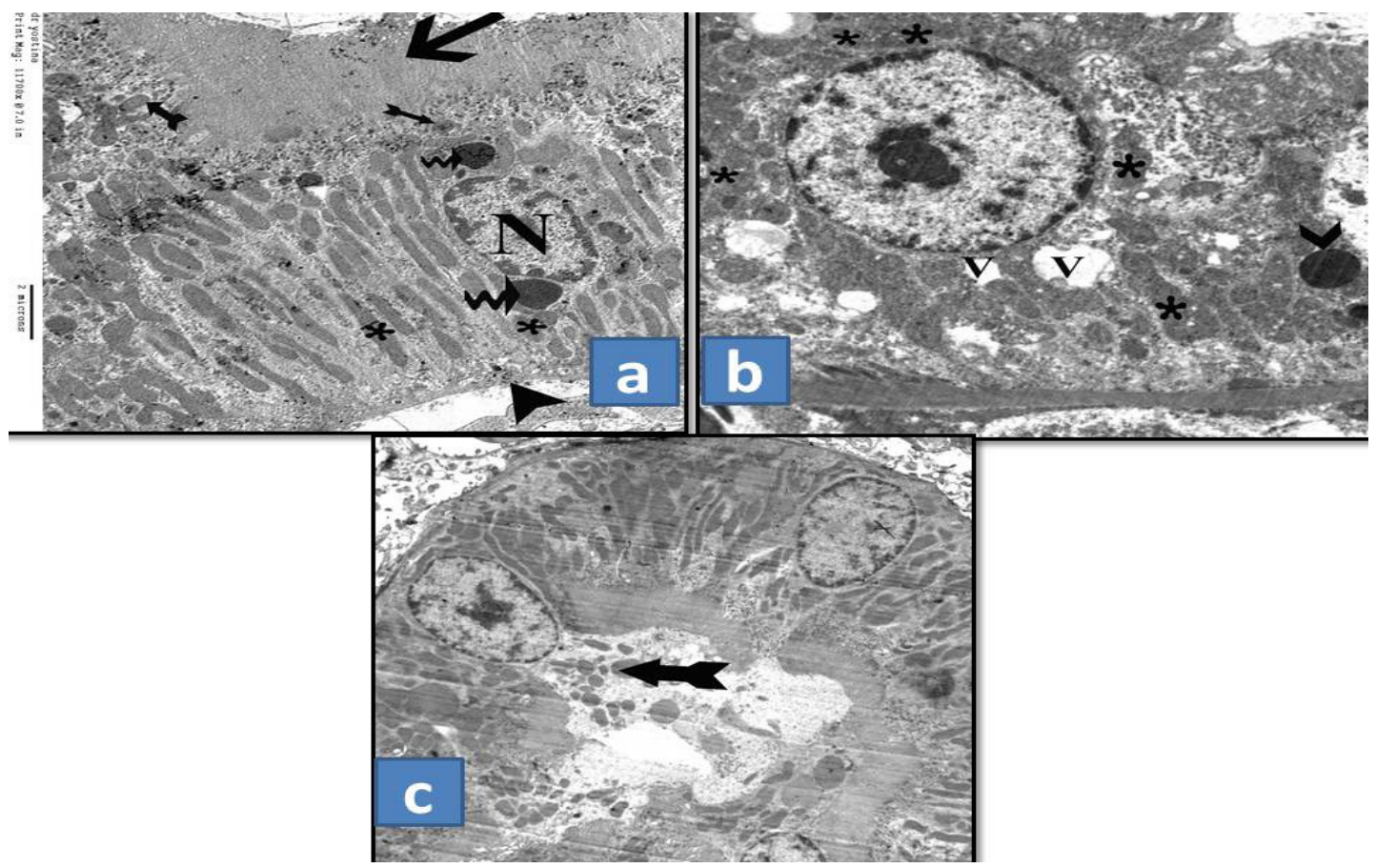

Fig. 5: EM of the PCTs of the renal cortex showing: a) Control group with PCTs cells resting on a thin basement membrane $(\triangleright)$, brush border $(\rightarrow)$, pinocytotic vesicles $(\smile)$, electron dense bodies $(\leadsto)$, euchromatic central nucleus $(\mathrm{N})$ and basal plasma membrane enfolding's with palisade arrangement of mitochondria (*) (Mic. Mag. X 2000). b) Esomeprazole group with cytoplasmic vacuoles (V), electron dense bodies (arrow head), and loss of mitochondrial palisade arrangement (*) (Mic. Mag. X 2000). c) Recovery group showing few PCTs' cells with disrupted apical cell membrane and extrusion of its organelles into their lumen $(\precsim$ ) (Mic. Mag. X1000).

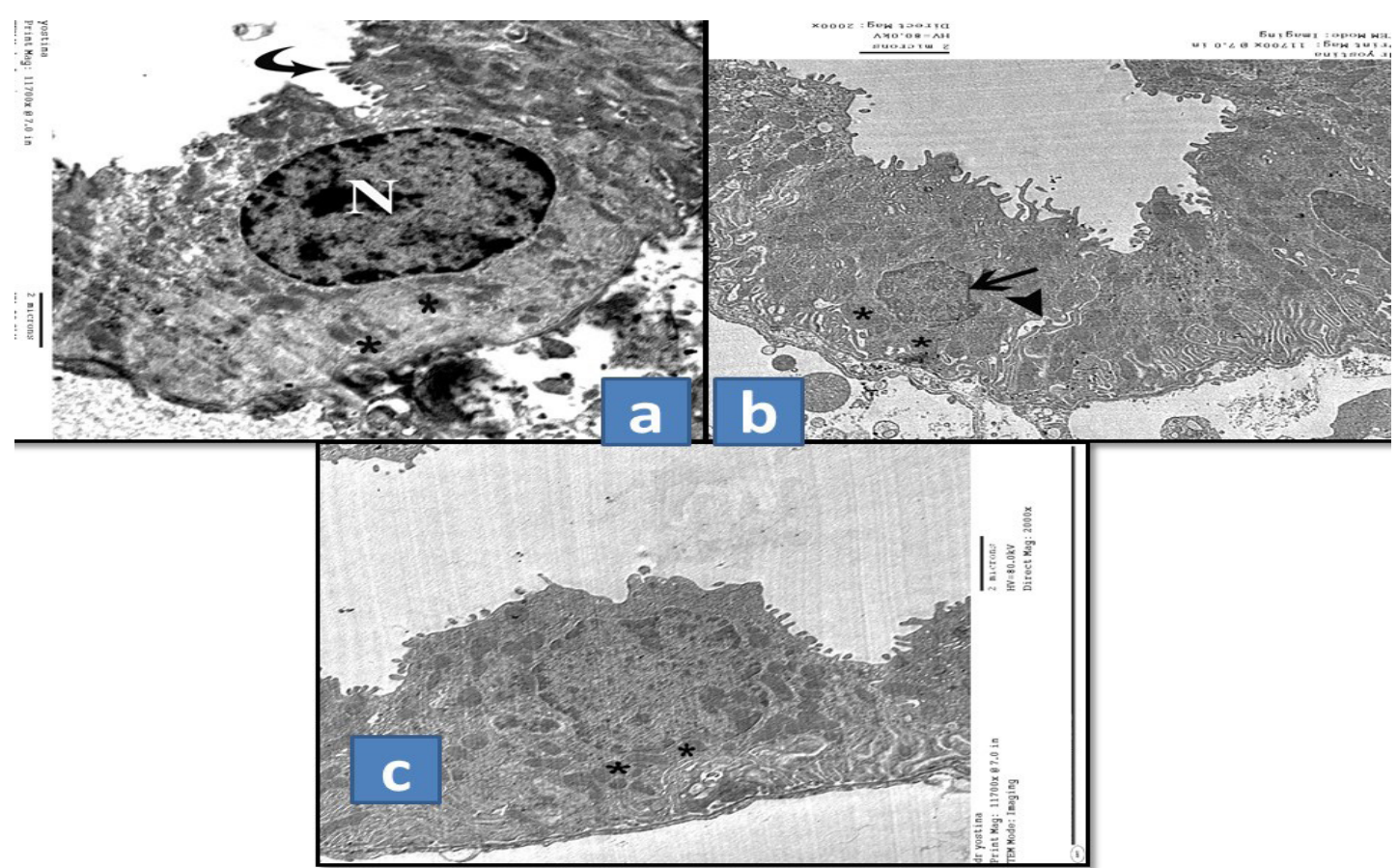

Fig. 6: EM of the DCTs of the renal cortex showing: a) Control group with cuboidal cells have few microvilli on its apical surface ( $\hookrightarrow$ ), euchromatic nucleus $(\mathrm{N})$ and basal arrangement of mitochondria $\left(^{*}\right)$, b) Esomeprazole group with widening of intercellular space $(\triangleright)$, irregular nuclear outlines $(\rightarrow)$, and loss of the basal arrangement of the mitochondria (*), c) Recovery group showing DCTs' cell with mild disarrangement of the mitochondria $(*)$ (Mic. Mag. X 2000). 


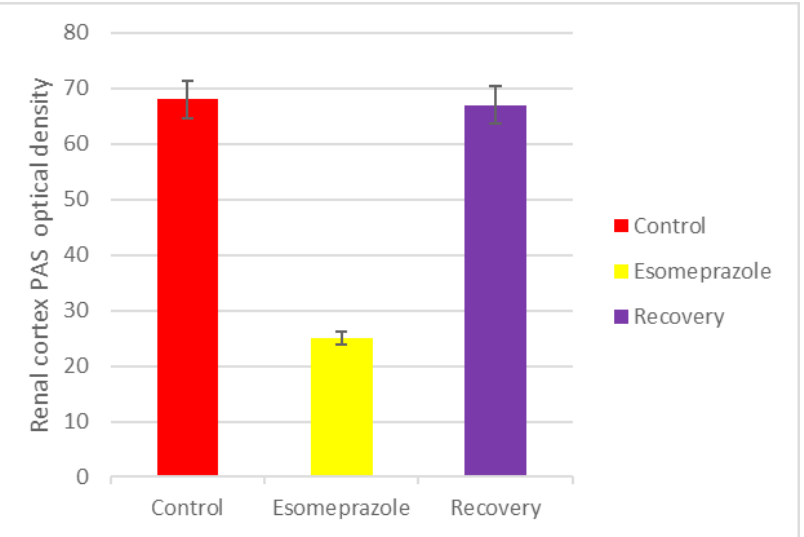

Histogram 1: The mean optical density of PAS in different studied groups expressed as mean $\mathrm{SD}$ a: $p<0.05$ significant decrease relative to control; $\mathrm{b}: p>0.05$ non-significant relative to control; $b \backslash: p<0.05$ significant increase relative to esomeprazole group

\section{DISCUSSION}

Kidney is a highly susceptible organ to the toxic effects of different noxious chemicals which is attributed to its unique anatomic and physiologic features. Anatomically, kidneys receive about $20 \%$ of the resting cardiac output and consequently any chemical in the systemic circulation will be delivered in high amounts to it. Physiologically, the process of urine concentration causes accumulation of the toxic agents in the tubular cells and their lumen. Therefore, a non-toxic concentration of certain chemical in the plasma may reach toxic concentration in the kidney (Klaassen, 2018) ${ }^{[22]}$.

The use of proton-pump inhibitors (PPIs) in the management of gastro-esophageal reflux disease (GERD) and other gastric related disorders has dramatically improved the options and welfare of this patient population. Esomeprazole is a recent PPI reduces gastric acid secretion by inhibiting proton pump in gastric parietal cells. In spite of its safety, many side effects have been reported especially its effect on the kidneys ${ }^{[10,23}$ and 24$]$.

The long-term exposure to proton pump inhibition especially esomeprazole impairs lysosomal acidification and enzyme activity which result in an accumulation of protein aggregates, increases the generation of reactive oxygen species $(\mathrm{ROS})^{[25]}$.

The present study designed to assess the effect of esomeprazole on the histological structure of the renal cortex of adult male albino rats using light and electron microscopic techniques and the capability of renal tissue to regenerate and recover after cessation of esomeprazole administration.

In the present research, H. and E. stained section of esomeprazole group showed congested glomerular capillaries and mononuclear cellular infiltration. Some proximal and distal convoluted tubules in the renal cortex also showed signs of degeneration in the form of cytoplasmic vacuolation, darkly stained nuclei together with nuclear extrusion into tubular lumen as well as intraluminal debris and lost brush border. Additionally, there were congested intertubular capillaries.

The congested glomerular capillaries could be attributed to the chemokines and cytokines released by reactive oxygen species (ROS) ${ }^{[26]}$. While The mononuclear cellular infiltration can be explained as an inflammatory response to eliminate a pathologic insult and to remove the injured tissue components in order to allow the tissue repair $^{[27]}$.

The cytoplasmic vacuolation, darkly stained nuclei together with nuclear extrusion into tubular lumen as well as intraluminal debris and lost brush border may be attributed to increased permeability of cell membranes in response to cell injury leading to an increase of intracellular water, which will accumulate within the cell, producing cytoplasmic vacuolation. Furthermore, the impaired mitochondrial oxygen uptake, and release of cytotoxic lysosomal enzymes into the cytosol besides increased calcium influx from the extracellular to the intracellular compartment and activation of calcium dependent phospholipases can lead to tubular vacuolar damage ${ }^{[28]}$.

Additionally, some renal tubular cells showed desquamation with lost brush border and nuclear extrusion. These may be attributed to the imbalance between the production of free radicals and antioxidant defense system induced by esomeprazole leading to oxidative stress with the liberation of oxygen free radicals resulting in renal tissue damage ${ }^{[25]}$.

As regards tubular darkly stained nuclei, this might be due to DNA damage caused by esomeprazole or shrinkage and clumping of the nuclear chromatin as a feature of necrosis ${ }^{[25,29]}$.

The present work revealed also some congested intertubular capillaries. This can be attributed to the interstitial edema which is common in acute interstitial nephritis. It is also might be due to dilatation and congestion of the vasa recta of the renal outer medulla ${ }^{[27]}$.

Regarding PAS results of the present study, there was minimal PAS reaction in the brush border of some PCTs with its focal interruption in esomeprazole group proved by statistical analysis to mean optical density of PAS reaction.

The focal loss of PAS reaction in the brush border of some PCT could be explained as a result of progressive acute cell swelling which causes disintegration of the actin core of microfilaments and the linker proteins that connect them to the cell membrane ${ }^{[31]}$.

As regards EM findings of the present research; it confirmed the previous light microscopic findings of esomeprazole group. It showed thickening of some glomerular basement membrane, effacement of some podocytes' foot processes, vacuolation and rarefaction of its cytoplasm. The thickening of some glomerular basement membrane was a feature of glomerulonephritis. It might be due to either thickening of the parietal layer proper 
or deposition of amorphous electron dense proteins on epithelial side of the parietal layer or within the membrane itself $^{[30]}$.

The effacement of some podocytes' foot processes is coincided to the finding of Deegens et al., (2008) ${ }^{[32]}$ Esomeprazole interfere with the structural components of the slit diaphragm, actin cytoskeleton of podocytes and the interaction between the podocytes and the glomerular basement membrane. While the cytoplasmic vacuolation and cytoplasmic rarefaction are considered to be features of acute cell swelling that occur secondary to loss of control of water uptake. Esomeprazole interfere with the regulatory mechanisms of cell volume by increasing cell membrane permeability, damaging sodium pump and interfering with synthesis of ATP thus depriving the sodium pump of its fuel. Consequently, dilated RER results with subsequent RER membranes fragmentation. So, water begins to accumulate in vesicles, with formation of cytoplasmic lakes and vacuoles. Moreover, the cytoplasmic rarefaction is most evident in the cells involved in rapid ion transport as the renal tubular epithelium ${ }^{[31,27]}$.

Furthermore, cytoplasmic vacuoles, dense bodies and loss of mitochondrial palisade arrangement were EM findings of the PCTs of esomeprazole group besides, widening of the intercellular spaces and irregular nuclear outlines in DCTs. Electron dense may be secondary lysosomes which result from engulfing of aggregated proteins or degenerated organelles as mitochondria. This also confirmed by Kamble et al., (2013) ${ }^{[33]}$ who illustrated presence of secondary lysosomes during their study of the effect of etoposide (cancer chemotherapeutic agent) on the rat kidney as an indication of degenerative activity.

Widening of the intercellular spaces of the DCTs may be the result of breaking down of the cellular junctions during cell injury and acute swelling process which occurs secondary to disruption of the cytoskeletal filaments. Along with suppression of the production and disintegration of the junctional adhesion molecules. Consequently, separation of the neighboring cells from each other. Another explanation is that when fluid leaks into and accumulates in the intercellular spaces; isolation of cells from each other ensues ${ }^{[29]}$.

In the present study, some tubular cells showed loss of apical cell membranes with the extrusion of some organelles. Cheville, (2009) ${ }^{[31]}$ referred to these cells as ghost cells and attributed them to be features of lytic necrosis. They developed secondary to massive intake of water, degradation of cytoplasmic proteins and rupture of membranes with release of the internal contents into the lumen.

Recovery group showed partial improvement in the previously mentioned histological changes which might be due to release of cell stress induced by esomeprazole. This is supported by Geevasinga et al., $(2005)^{[34]}$ during their study on esomeprazole-induced interstitial nephritis. They proved that esomeprazole withdrawal could lead to improvement of the histological structure of the renal cortex, consequently improvement of the renal function. Moreover, the study made by Wilcox and Mattia, (2009) ${ }^{[35]}$ of esomeprazole-induced colitis has proved nearly restoration of its histological structure after stoppage of esomeprazole.

\section{CONCLUSION}

Based on the current study and from all previously mentioned histological results, it could be concluded that, esomeprazole has a damaging effect on the renal cortex of adult male albino rats which could be partially improved if left to recover.

\section{CONFLICTS OF INTEREST}

There are no conflicts of interest

\section{REFERENCES}

1. Yoichi, S.T.I., Tomohisa, I., Yukinobu, G., Tomoaki, I.M.N., Nobuaki, S., Katsunori, S. and Kazuhiko I. (2008): Effects of acid antisecretory drugs on mucus barrier of the rat against 5 fluorouracil induced gastrointestinal mucositis. Scandinavian Journal of Gastroenterology, 43(5): 531-537.

2. Shin, J.M., Munson, K., Vagin, O. and Sachs, G. (2009): The gastric HK-ATPase: structure, function, and inhibition. Pflügers Archiv-European Journal of Physiology, 457(3): 609-622.

3. Miner Jr, P., Katz, P.O., Chen, Y., and Sostek, M. (2003): Gastric acid control with esomeprazole, lansoprazole, omeprazole, pantoprazole, and rabeprazole: a five-way crossover study. The American Journal of gastroenterology, 98(12): 2616-2620.

4. Lind, T., Rydberg, L., Kylebäck, A., Jonsson, A., Andersson, T. and Hasselgren, G. (2000): Esomeprazole provides improved acid control vs. omeprazole In patients with symptoms of gastro-oesophageal reflux disease. Alimentary Pharmacology and Therapeutics, 14(7): 861-867.

5. Thomson, A.B., Sauve, M.D., Kassam, N., and Kamitakahara, H. (2010): Safety of the long-term use of proton pump inhibitors. World journal of gastroenterology, 16(19): 2323-2330.

6. Ruffenach, S.J., Siskind, M.S., and Lien, Y. (1992): Acute interstitial nephritis due to omeprazole. The American Journal of Medicine, 93(4): 472-473.

7. Myers, R.P., McLaughlin, K., and Hollomby, D.J. (2001): Acute interstitial nephritis due to omeprazole. The American Journal of Gastroenterology, 96(12): 3428-3431.

8. Ra, A., and Tobe, S.W. (2004): Acute interstitial nephritis due to pantoprazole. Annals of Pharmacotherapy, 38(1): 41-45.

9. Härmark, L., Van Der Wiel, H.E., De Groot, M.C., and Van Grootheest, A. (2007): Proton 
pump inhibitor induced acute interstitial nephritis. British Journal of Clinical Pharmacology, 64(6): 819-823.

10. Geevasinga, N., Coleman, P.L., Webster, A.C. and Roger, S.D. (2006): Proton pump inhibitors and acute interstitial nephritis. Clinical Gastroenterology and Hepatology, 4(5): 597-604.

11. Simpson, I.J., Marshall, M.R., Pilmore, H., Manley, P., Williams, L., Thein, H., and Voss, D. (2006): Proton pump inhibitors and acute interstitial nephritis: report and analysis of 15 cases. Nephrology, 11(5): 381-385.

12. Sampathkumar, K., Ramalingam, R., Prabakar, A., and Abraham, A. (2013): Acute interstitial nephritis due to proton pump inhibitors. Indian Journal of Nephrology, 23(4): 304-307.

13. Antoniou, T., Macdonald, E.M., Hollands, S., Gomes, T., Mamdani, M.M., Garg, A.X. and Juurlink, D.N. (2015): Proton pump inhibitors and the risk of acute kidney injury in older patients: a population-based cohort study. Canadian Medical Assosciation Journal open, 3(2): E166-E171.

14. Lazarus, B., Chen, Y., Wilson, F.P., Sang, Y., Chang, A.R., Coresh, J., \& Grams, M.E. (2016): Proton pump inhibitor use and the risk of chronic kidney disease. Journal of American Medical Assosciation internal medicine, 176(2): 238-246.

15. Xie, Y., Bowe, B., Li, T., Xian, H., Balasubramanian, S., and Al-Aly, Z. (2016): Proton pump inhibitors and risk of incident CKD and progression to ESRD. Journal of the American Society of Nephrology, 27 :1-11.

16. Arora, P., Gupta, A., Golzy, M., Patel, N., Carter, R.L., Jalal, K., and Lohr, J.W. (2016): Proton pump inhibitors are associated with increased risk of development of chronic kidney disease. BioMedical Central nephrology, 17(1): 112-120.

17. Moledina, D.G., and Perazella, M.A. (2016): PPIs and kidney disease: from AIN to CKD. Journal of Nephrology, 29(5): 611-616.

18. Bastaki, S.M., Chandranath, I.S. and Singh, J. (2008): The anti-secretory and anti-ulcer activities of esomeprazole in comparison with omeprazole in the stomach of rats and rabbits. Molecular and Cellular Bbiochemistry, 309(1-2): 167-175.

19. Limaye, R.P., Pendhari, S.R. and Joshi, K.S. (2017): Proton pump inhibitors: are they safe on kidneys: a histopathological study. International Journal of Basic \& Clinical Pharmacology, 5(4): 1187-1192.

20. Rtibi, K., Jabri, M.A., Selmi, S., Sebai, H., Marie, J.C., Amri, M., El-Benna, J. (2016): Preventive effect of carob (Ceratonia siliqua L.) in dextran sulfate sodium-induced ulcerative colitis in rat. Royal Society of Chemistry Advances, 6(24): 19992-20000.

21. Suvarna, K.S., Layton, C. and Bancroft, J.D. (2019): Bancroft's Theory and Practice of Histological Techniques ( $8^{\text {th }}$ ed.): Elsevier Health Sciences.China pp.126-139 and 434-470.

22. Klaassen, C.D. (2018): Casarett \& Doulls Toxicology The Basic Science of Poisons $\left(8^{\text {th }}\right.$ ed.): McGraw-Hill Education.pp. 665-690.

23. Vachhani, R., Olds, G. and Velanovich, V. (2009): Esomeprazole: a proton pump inhibitor. Expert Review of Gastroenterology and Hepatology, 3(1): 15-27.

24. Saccar, C.L. (2009): The pharmacology of esomeprazole and its role in gastric acid related diseases. Expert Opinion on Drug Metabolism \& Toxicology, 5(9): 1113-1125.

25. Yepuri, G., Sukhovershin, R., Nazari-Shafti, T.Z., Petrascheck, M., Ghebre, Y.T. and Cooke, J.P. (2016): Proton pump inhibitors accelerate endothelial senescence. Circulation research, 118(12): 36-42.

26. Klaunig, J.E. and Kamendulis, L.M. (2009): The role of oxidative stress in carcinogenesis. Annual Review of Pharmacology and Toxicology, 44:239-267.

27. Strayer, D.S., Rubin, E., Saffitz, J.E. and Schiller, A.L. (2015): Rubin's Pathology: Clinicopathologic Foundations of Medicine ( $7^{\text {th }}$ ed.): Wolters Kluwer Health.pp. 3-55 and 903-950.

28. Swelim, H.H. and Sakr,A.A. (2004): Ultrastructural study of renal tubular damage induced by captopril in adult and fetal mice. Egyptian Journal of Hospital Medicine, 17: 20-43.

29. Haschek, W.M., Bolon, B., Rousseaux, C.G. and Wallig, M.A. (2018): Fundamentals of Toxicologic Pathology ( $3^{\text {rd }}$ ed.): Elsevier Science.pp. 59-81 and pp. 213-260.

30. Kumar, V., Abbas, A.K., Aster, J.C. and Perkins, J.A. (2018): Robbins Basic Pathology (Tenth ed.): Elsevier, Canada. pp.31-45 and 549-578.

31. Cheville, N.F. (2009): Ultrastructural Pathology: The Comparative Cellular Basis of Disease (Second ed.): Wiley, Singapore. pp. 695-711.

32. Deegens, J.K., Dijkman, H.B., Borm, G.F., Steenbergen, E.J., Van Den Berg, J.G., Weening, J.J. and Wetzels, J.F. (2008): Podocyte foot process effacement as a diagnostic tool in focal segmental glomerulosclerosis. Kidney International, 74(12): 1568-1576. 
33. Kamble, P., Kulkarni, S. and Bhiwgade, D. (2013): Ultrastructural and antioxidant studies of etoposide treated kidney of rat. Journal of Cancer Science and Therapy, 5(4): 137-141.

34. Geevasinga, N., Kairaitis, L., Rangan, G.K., and Coleman, P.L. (2005): Acute interstitial nephritis secondary to esomeprazole. Medical Journal of Australia, 182(5): 235-236.

35. Wilcox, G.M., and Mattia, A.R. (2009): Microscopic colitis associated with omeprazole and esomeprazole exposure. Journal of Clinical Gastroenterology, 43(6): 551-553. 


\section{الملخص العربى - (المى}

\section{دراسة هستولوجية لتأثير عقار مثبط مضخة البروتون (الإيزوميبرازول)

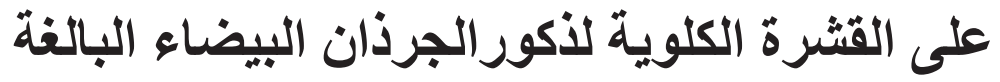

\section{يوستينا صموئيل صليب، سماح قنديل السيد، كوثر عباس الميهى، عبد المنعم فريد زمزم

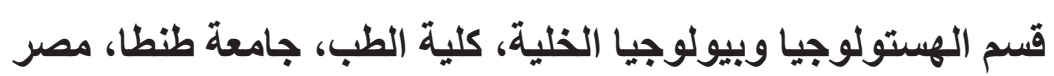

خلفية البحث: يعتبر الإيزوميبر ازول واحد من مثبطات مضخة البرونون المستخدمة في علاج إضطر ابات الجهاز الهضمي. وعلى الرغم من سلامته فى الإستخدام إلا أنه قد يؤدي إلي العديد من الآتار الجانبية ، وخاصة إلتهاب الكلية الخلالي الحاد الذي قد يتطور إلى الفشل الكلوي الحاد. الهذف: يهدف هذا العمل إلى در اسة تأثثير عقار مثبط مضخة البروتون (الإيزوميير ازول) على التركيب النسيجي للقشرة الكلوية لذكور الجرذان البيضاء البالغة ، وكذللك تأثثر توقف التعرض لهذا العقار. مواد وطرق البحث: تم تقسيم ثلاثثن من ذكور الجرذان البيضاء البالغين إلى ثلاثة مجمو عات (10جرذان لكل مجموعة) ، المجمو عة الضابطة ، مجموعة الإيزوميبر ازول: حيث تلقت الجرذان 5مجم / كجم في اليوم إيزوميبر ازول عن طريق الفم لمدة 4 أسابيع، ومجموعة التعافي : حيث تلقت الجرذان الإيزوميبرازول عن طريق الفم بجر عة 5مجم/كجم يوميا لمدة 4 أسابيع ثم تركت بدون علاج لمدة 4 أسابيع أخرى. وبعد ذلك أخذت عينات من القشرة الكلوية وذلك حتي يتم فحصها بو اسطة المجهر الضوئي و الإليكتروني النافذ. النتائج: أظهرت مجمو عة الإيزوميبرازول إنكماش لبعض الكبيات مع وجود إتساع في فراغ بومان , إحتوت بعض كض الكبيبات و الخلايا المبطنة للانابيب الكلوية علي فجوات وصبغه داكنه للأنويه. أظهر كاثف شيف الاحمرى الدورى تفاعل قليل ذو دلالة إحصائية في حدود الفرشاة للنبيبات الملفوفة القريبة مع إنقطاعها البؤري. وكذلك تغييرات في التركيب الدقيق لكل من كبسولة بومان ,النبيبات الملفوفة القريبة, النبيبات الملفوفة البعيدة. وفي مجموعة التعافي لوحظ تحسن جزئي في التغيير ات النسيجية السابق ذكر ها. الإستتتاج: أن عقار الإيزومييرازول قد أحدث تغييرات نسيجية مرضية علي القشرة الكلوية لذكور الجرذان البيضاء البالغة و التي يمكن تحسينها جزئيا إذا تركت للتعافي. 